\title{
The Development of the Metacognitive Thinking Skills
}

\section{Scale}

\author{
Murat TUNCER (Corresponding author) \\ Dept. of Educational Sciences, Frrat University \\ 23119, Elazig TURKEY \\ Tel: +90-424-237-0000 E-mail: mtuncer@firat.edu.tr \\ Feyzi KAYSİ \\ Istanbul University \\ TURKEY \\ Tel: +90 2124737070 E-mail: feyzikaysi@gmail.com \\ Accepted: March 01, 2013 Published: May 01, 2013 \\ Doi:10.5296/ijld.v3i2.3449 URL: http://dx.doi.org/10.5296/ijld.v3i2.3449
}

\begin{abstract}
It is observed that majority of recent studies on cognitive learning are dealing with metacognition. Metacognition is used to follow and regulate cognitive processes such as learning, problem solving, comprehension, reasoning and memory. Therefore, it is possible to gather all information about a problem encountered by the individuals, including its solution, comprehension of its outline or essence and reasoning for solving it. Individuals' development of metacognitive thinking skills will allow them to act more efficiently in their professions. In this research, a scale was developed in order to measure these metacognitive thinking skills. The scale was proved valid and reliable through employment of exploratory and confirmatory factor analysis.
\end{abstract}

Keywords: Metacognition, Learning, Scale Development, Metacognitive Thinking

\section{Introduction}

Cognitive development is the development of an individual in terms of understanding and learning the world around him. It is the development of active mental activities. Cognitive development is process which lasts from childhood to adulthood. In this process, the ways to understand the environment and the world for an individual become complicated and effective. According to Senemoğlu (1997), cognitive development is a progressive process which evolves from individual behaviors that are regulated by others to behaviors that are determined by the individual himself.

It is observed that majority of recent studies on cognitive learning are dealing with metacognition. The concept of metacognition was first used by Flavell. Flavell (1985) defines metacognition as "knowledge and cognition on cognitive phenomenon" and "one's own knowledge on his self-cognitive processes and use of this knowledge in order to monitor cognitive processes". In the relevant literature, there are other concepts that are used as synonyms for the concept of metacognition. As Steinbach (2008) states, some researchers use several concepts such as self-management, upper level thinking or learning instead of metacognition. Similarly Veenman, Van Hout-Wolters and Afflerbach (2006) preferred to use 
different concepts like metacognitive beliefs, executive skill, metacomponents, high order skills and judgments of learning (Aktürk \& Şahin, 2011).

Woolfolk (1998) considers the concept of concept of metacognition as "upper level form of thinking" in which individuals think and monitor on their own process of thoughts. Ülgen (1997) states that metacognition is significant in terms of individuals' understanding of their own cognitive processes. It also enables individuals to regulate these processes through effective learning. An individual, who has metacognitive thinking skills, can monitor, plan and execute every step in a thinking process. Therefore, his efficiency and quality in learning can be increased. According to Karakelle (2012), metacognitive learning can be used to monitor and regulate cognitive processes of learning, problem solving, comprehension and memory. Therefore, it is possible to gather all information about a problem encountered by the individuals, including its solution, comprehension of its outline or essence and reasoning for solving it. According to Doğanay (2007), the concept of thinking is redefined as critical thinking, reasoning, cognitive awareness by scholars of several different disciplines. Doğanay recognizes that the concept of "metacognitive thinking skills" is a common name of skills that not only help current knowledge to be remembered and understood but also help them to be organized and used. Drmrod (1990) listed following characteristics of metacognition:

- It is the awareness of an individual in terms of his own learning, memory and realistic accomplishment of his learning tasks.

- It is about an individual's awareness that if a learning method is effective or ineffective.

- It is an approach of planning that is possibly successful for a learning task.

- It is the use of effective strategies of learning.

- It enables an individual to monitor his current status of learning. It shows an individual's awareness that if an individual successfully learns knowledge or not.

- It is about individual's cognition of effective methods that are used for recalling stored knowledge.

According to Kaya (2008), "metacognitive thinking skills" refer to all skills of critical and creative thinking, decision making and problem solving. Critical thinking is a form of thinking which consists of mental processes such as reasoning and assessment. Decision making is defined as a process of sufficiently decreasing doubts and uncertainties while choosing the right options among many options. This definition focuses on data collecting function of decision making. Here, it is more important to decrease uncertainties rather than eliminating them. Very few decisions are made in a full certainty (Balk1s, 2006). The third component, problem solving is to carry problem status into solution and to overcome difficulties. The aim of decision making is to choose or evaluate the best option (Sternberg \& Grigorenko, 2000:39). According to Gagne, problem solving is the most complicated mental skill. As a process, it includes several activities such as trial and error, acquisition of insight and finding cause-effect relationships (Demirel \& Ün, 1987). The individual, who solves the problem, not only uses his previous learning but also learns during the process.

As it is seen, metacognitive skills are very important in terms of several professions. Individuals' development of metacognitive thinking skills will provide a better performance in their professions. In professional life, metacognitive thinking skills play a significant role for individuals in determining the problems that they encounter and in developing proper ways of solutions. With regard to this significance, in this study a scale was developed to measure metacognitive thinking skills. 


\section{Macrothink}

\section{Method}

The researchers wrote the items of the metacognitive thinking skills (MTS) scale in accordance with literature review. The scale development study was applied to 325 students of Istanbul University Technical Sciences Institute, Departments of Computer Planning, Electronic Technology and Control and Automation Technology. The scale is five point Likert scale. The answers to the items in the scale are as follows: $5=$ strongly agree, $4=$ agree, $3=$ neither agree nor disagree, $2=$ disagree, $1=$ strongly disagree. The original scale consisted of 80 items however 23 items were removed from the scale after literature review and concerning experts' opinions. The final version has 57 items. The scale was tested through exploratory factor analysis (EFA) and confirmatory factor analysis (CFA).

\section{Explorative Factor Analysis of the MTS Scale}

The metacognitive thinking skills scale was tested through confirmatory factor analysis concerning literature review and experts' opinions. Exploratory factor analysis is a process for finding factors from relationships between variables and for developing theories. The metacognitive thinking skills scale's scree plot graphic, which was acquired from exploratory factor analysis, is given on Figure 1.

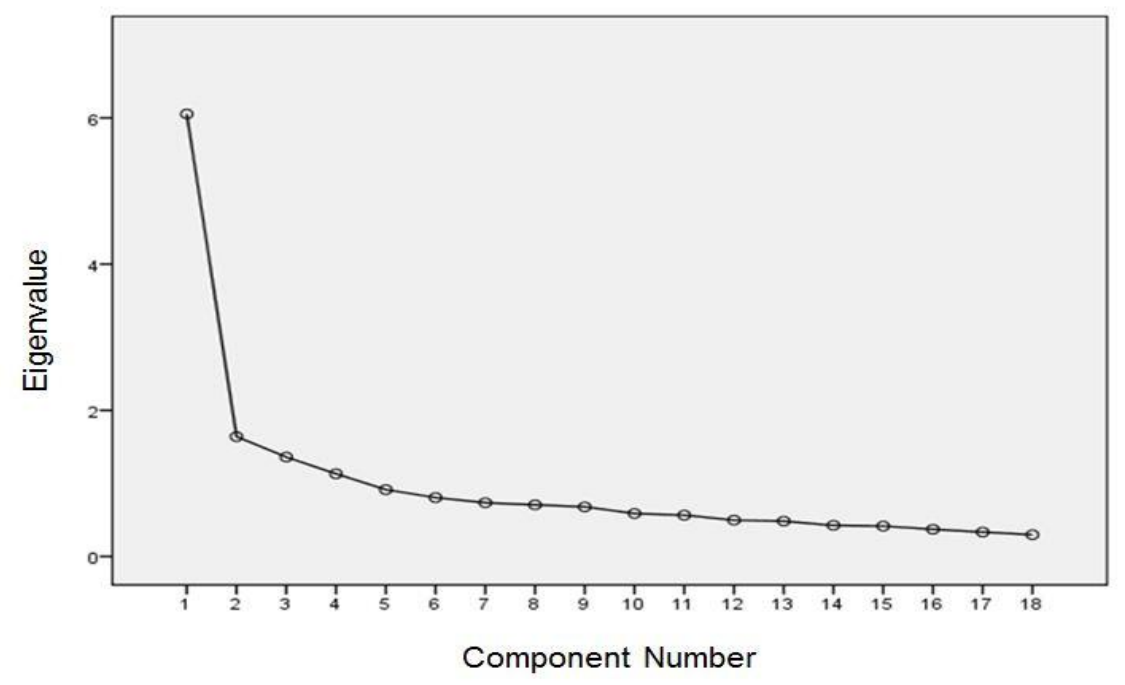

Figure 1. Metacognitive Thinking Skills Scree Plot Graphic

According to metacognitive thinking skills scree plot graphic, it is observed that the graphic expands horizontally after the 4th item, and then there is no significant decrease. In consideration of other factor variances' little contribution, these factors were excluded and it was decided that the scale consists of four factors. In the following, the results of KMO and Bartlett's test of sphericity $\left(\mathrm{KMO}=, 885 ; \mathrm{X}^{2}=1962,318, \mathrm{sd}=153, \mathrm{p}=, 000\right)$ indicated that data group is available for factor analysis. The structure of the MTS scale and item factor loadings can be seen on Table 1. 
Table 1. The Structure of the Metacognitive Thinking Skills Scale and Item Factor Loadings

\begin{tabular}{|c|c|c|c|c|c|}
\hline \multirow{2}{*}{\multicolumn{2}{|c|}{ Item Number }} & \multicolumn{4}{|c|}{ Factors and Item Factor Loadings } \\
\hline & & \multirow{2}{*}{$\begin{array}{l}\text { F1 } \\
, 728\end{array}$} & \multirow[t]{2}{*}{$\mathbf{F 2}$} & \multirow[t]{2}{*}{ F3 } & \multirow[t]{2}{*}{ F4 } \\
\hline 8 & I create samples to make knowledge more meaningful. & & & & \\
\hline 2 & I try different working methods to obtain the best solution. & ,682 & & & \\
\hline 7 & $\begin{array}{l}\text { Before beginning a new task, I think of what I will need to } \\
\text { learn the task }\end{array}$ & ,666 & & & \\
\hline 3 & I can learn better due to my previous knowledge. & ,636 & & & \\
\hline 4 & $\begin{array}{l}\text { After I complete my task, I repeat significant points in order } \\
\text { to assure that I have learned it. }\end{array}$ &, 528 & & & \\
\hline 24 & After solving a problem, I think if I could find a better way & & ,781 & & \\
\hline 25 & $\begin{array}{l}\text { While solving problems, I ask questions to myself in order } \\
\text { to find different ways of solution. }\end{array}$ & & ,738 & & \\
\hline 23 & $\begin{array}{l}\text { When I cannot solve a problem, I ask questions to myself to } \\
\text { understand why I cannot solve it. }\end{array}$ & & ,637 & & \\
\hline 27 & $\begin{array}{l}\text { After I solve a problem, I compare my results with my } \\
\text { friends' result and evaluate the solution. }\end{array}$ & &, 578 & & \\
\hline 26 & $\begin{array}{l}\text { When I read a problem, I think of similar problems that I } \\
\text { solved before and make connections concerning the } \\
\text { differences between the new problem and the old ones. }\end{array}$ & &, 566 & & \\
\hline 14 & I think about how my decisions can affect others. & & & ,762 & \\
\hline 15 & I think of the consequences of my decision. & & & ,744 & \\
\hline 13 & I think of options before I make a decision.. & & & ,697 & \\
\hline 21 & $\begin{array}{l}\text { Before I make a decision, I think carefully what, how and to } \\
\text { whom my decision will address. }\end{array}$ & & & ,628 & \\
\hline 38 & $\begin{array}{l}\text { I am aware of thinking technique or strategies concerning } \\
\text { the topic I am working on. }\end{array}$ & & & & ,729 \\
\hline 40 & I am aware how my thinking mechanism works. & & & & ,718 \\
\hline 39 & I correct my errors. & & & & ,656 \\
\hline \multirow[t]{8}{*}{41} & $\begin{array}{l}\text { I change my thinking technique or strategy of my work } \\
\text { when necessary. }\end{array}$ & & & &, 573 \\
\hline & Factor Eigenvalues & 6,054 & 1,639 & 1,360 & 1,131 \\
\hline & Variance Explained & 33,633 & 9,108 & 7,556 & 6,281 \\
\hline & Total Variance Explained \% & 33,633 & 42,741 & 50,297 & 56,579 \\
\hline & KMO Adequacy Scale & \multicolumn{4}{|c|}{0,885} \\
\hline & Bartlett's Test & \multicolumn{4}{|c|}{$X^{2}=1962,318, \mathrm{sd}=153, \mathrm{pi}=, 000$} \\
\hline & Cronbach's Alpha Coefficient of Factors & ,786 & ,767 & ,784 & ,704 \\
\hline & Cronbach's Alpha Coefficient of all Scale & \multicolumn{4}{|c|}{, 881} \\
\hline
\end{tabular}

Labeling study was done concerning this factor structure. The items in the scale was thought to be classified as follows: Items 2, 3, 4, 5 and 8 can be classified under the category "thinking skills", items 23, 24, 25, 26 and 27 can be classified under the category " reflective thinking skills towards problems solving", items $13,14,15$ and 21 can be classified under the category "decision making skills" and items 38,39, 40 and 41can be classified under the category "alternative skills of evaluation". Loading values of items in the first factor vary between ,528 and ,728, load values in the second factor vary between ,566 and ,781, load values in the third factor vary between ,628 and ,762 and load values in the fourth factor vary between ,573 and ,729. According to these results, it is a four factor scale and all values have adequate load values in order to be place in the final scale. Furthermore, Cronbach's Alpha coefficient of the Metacognitive Thinking Skills (MTS) scale was calculated ,881. 


\section{Macrothink

\section{Confirmatory Factor Analysis of the MTS Scale}

Confirmatory Factor Analysis (CFA) can be defined as an analysis for testing and confirming or not confirming of a previously built structure (Tuncer, 2011). As Bayram mentioned, CFA models are generally used for explaining patterns of relationship between several latent structures. In order to test model-data fit, $\mathrm{X}^{2}$ (Chi-Square Goodness of fit), $\mathrm{X}^{2} / \mathrm{sd}$ (Chi-Square with the degrees of freedom), Goodness of fit (GFI), also known as goodness indexes, Bentler's comparative fit index (CFI), Root Mean Square of Approximation-(RMSEA) and Standardized Root Mean Square Residual (SRMR) are commonly used (Stapleton, 1997). Confirmatory factor analyses of the MTS scale are shown on figure 2 .

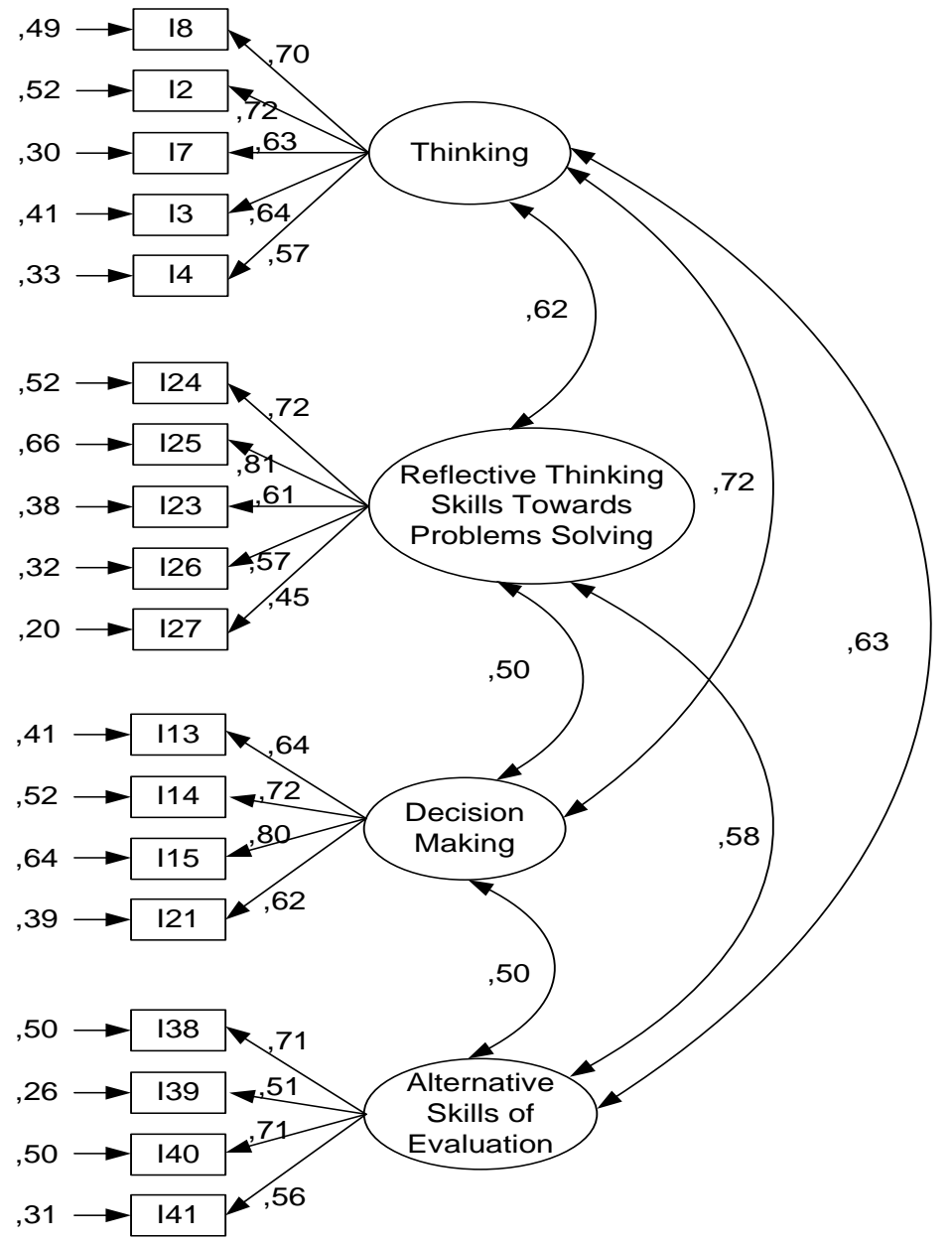

Figure 2. Confirmatory Factor Analysis of the Metacognitive Thinking Skills Scale The error and correlation values concerning four-factor structure of the scale are shown on figure 2. Fit indexes obtained from confirmatory factor analysis are presented on table 2.

Table 2. Fit Indexes of the Metacognitive Thinking Skills Scale

\begin{tabular}{lllllllll}
\hline CMIN & DF & P & CMIN/DF & CFI & GFI & AGFI & RMSEA & SRMR \\
\hline 261,485 & 129 &, 000 & 2,027 &, 928 &, 918 &, 891 &, 056 &, 0519
\end{tabular}

According to the results of confirmatory factor analysis, it was found that $\mathrm{cmin}=261,485, \mathrm{df}=$ 129 and $\mathrm{p}=, 000$. Thus, cmin/df ratio is 2,027 and gfi value is ,918. In addition, srmr value is ,0519, rmsea value ,056 and cfi value is, 928 . 


\section{Discussion and Conclusion}

According to the results of exploratory factor analysis of the metacognitive thinking skills scale, KMO value is ,885. As a result of Bartlett's sphericity test, $X^{2}$ is found 1962,318 and $\mathrm{p}$ was found, 000 . Exploratory factor analysis indicated that four-factor structure of the scale was able to explain $56,579 \%$ of the total variance.

Confirmatory factor analysis helped to evaluate model-data fit. There are several types of analysis to test model-data fit. $\mathrm{X}^{2}$ (Chi-Square Goodness of fit), $\mathrm{X}^{2} / \mathrm{sd}$ (Chi-Square with the degrees of freedom), Goodness of fit (GFI), also known as goodness indexes, Bentler's comparative fit index (CFI), Root Mean Square of Approximation-(RMSEA) and Standardized Root Mean Square Residual (SRMR) are among these analyses(Stapleton, 1997). Among these fit indexes, Chi-Square Goodness of fit $\left(\mathrm{X}^{2}\right)$ shows to what extent the observed correlation matrix diverges from theoretical correlation matrix. A low $\mathrm{X}^{2}$ value is the indication of a good model-data fit (Çokluk et al., 2010). The measure of fit $\left(\mathrm{X}^{2} / \mathrm{df}\right)$ refers to the division of Chi-Square value with degrees of freedom. If the ratio obtained remains below 2 or 3, then there is an excellent fit (Schreiber et al., 2006). If the ratio remains below 5, there is an indication of an average fit (Sümer, 2000). Apart from these, there is a fit index known as goodness of fit index (GFI). GFI has values ranging between 0,00 and 1,00. Negative values are theoretically meaningless values. As the sample is extended, GFI produces more coherent results. If GFI's values are over ,95, then model-data fit is excellent Schreiber et al., 2006). Nevertheless, if GFI's values are above ,85, then model-data fit is regarded sufficient (Sümer, 2000).

Comparative fit index (CFI) compares current model with the null model which assumes that there is no relationship between implicit variables. CFI has values ranging between 0,00 and 1,00. If a value of ,90 or is acquired, then it is an acceptable value for CFI index. A value of ,95 or above indicates data fit perfection (Sümer, 2000). If the index has a value of, 90 or above, then it expresses that $90 \%$ of covariance in data group can be explained by the suggested model. Other fit indexes are Root Mean Square of Approximation-(RMSEA) and Standardized Root Mean Square Residual (SRMR). SRMR is the average difference of latent variables and covariances. If the values of RMSEA and SRMR are close to 0 or less than ,05, then there is an excellent model-data fit (Sümer, 2000). Nevertheless, values less than ,08 are also considered as sufficient values for model-data fit. (Schreiber et al. 2006). For AGFI index, 80 and above are considered sufficient (Sümer, 2000).

In the stage of evaluating the fitness of the model and data, which is established through confirmatory factor analysis, SRMR value is 0,519 and RMSEA value is ,056 for the metacognitive thinking skills scale. Further, GIF value is found ,918 and AGFI value is found ,891. All these values are indicators of a sufficient fit. CFI value is found ,928. As it is over ,90, it is observed that $90 \%$ of the covariance in data group can be explained through suggested model. All these findings can be interpreted that the scale development has been successful.

\section{References}

Aktürk, A. O. \& Şahin, İ. (2011). Metacognition and computer teaching. Selçuk University Journal of Ahmet Keleşoğlu Education Faculty, 31, 383-407.

Balkıs, M. (2006). The relationships between student teachers' procrastination behaviors and thinking styles and decision making styles. Dokuz Eylül University Institute of Educational Sciences, Department of Educational Sciences, Phd Thesis.

Bayram, N. (2010). Introduction to structural equation modeling: Amos Applications. Bursa: Ezgi Bookstore.

Çokluk, Ö., Şekercioğlu, G. \& Büyüköztürk Ş., (2010). Multivariate statistics for the social sciences: SPSS and LISREL Applied. Ankara: PegemA Publishing. 
Doğanay, A. (2007). Teaching metacognition skills. Doğanay, A. (Ed.), Principles and Methods of Teaching. Ankara: Pegem A Publishing.

Demirel, Ö. \& Ün K. (1987). Study Terms: Instructions, Turkish-English, English-Turkish dictionary. Ankara: Şafak Printing House.

Drmrod, J. E. (1990). Human learning. Macmillan P. Company. New York.

Flavell, J. H. (1985). Cognitive Development. ( 2nd ed.) Englewood Cliffs, NJ. Prentice Hall.

Kaya, B. (2008). Assessing social studies preservice teachers' self-efficacy towards teaching thinking skills. Unpublished Phd Thesis. Gazi University, Institute of Educational Sciences.

Karakelle, S. (2012). Interrelations between metacognitive awareness, perceived problem solving, intelligence and need for cognition. Education and Science, Vol 37, Number 164.

Ülgen, G. (1997). Educational psychology (3rd Edition). İstanbul: Alkım Publishing.

Senemoğlu, N. (1997). Development, Learning and Teaching: From Theory to Practice. Ankara: Spot Printing.

Schreiber, J., B., Stage, F., K., King, J., Nora, A. \& Barlow, E., A. (2006). Reporting structural equation modeling and confirmatory factor analysis results: A Review. The Journal of Educational Research, July/August, Vol. 99, No. 6.

Stapleton, C. D. (1997). Basic Concepts in Exploratory Factor Analysis as a Tool to Evaluate Score Validity: A right-brained approach. http://ericae.net/ft/tamu/Efa.htm

Steinbach, J., C. (2008). The effect of metacognitive strategy instruction on writing. University of Kentucky

Sternberg, R.J. \& Grigorenko, E. (2000). Teaching thinking for successful intelligence. U.S.A.:SkyLight Professional Development, Arlington Heights.

Sümer, N. (2000). Structural equation models: basic concepts and applications. Türk Psikoloji Yazllarl, 3 (6), 74-79.

Tuncer, M. (2011). Adaptation of adolescent future expectations scale. International Periodical For The Languages, Literature and History of Turkish or Turkic, Vol 6(3), 1265-1275.

Veenman, M.V. J., Van Hout-Wolters, B. \& Afflerbach, P. (2006). Metacognition and learning: conceptual and methodological considerations. Metacognition Learning, 1: 3-14.

Woolfolk, E.A. (1998). Educational psychology. USA: Allyn Bacon. 